\title{
Sulphur bath and mud pack treatment for rheumatoid arthritis at the Dead Sea area
}

\author{
S Sukenik, D Buskila, L Neumann, A Kleiner-Baumgarten, S Zimlichman, J Horowitz
}

\begin{abstract}
Forty patients with classical or definite rheumatoid arthritis in a stage of active disease were treated for two weeks at a spa hotel. The patients were divided into four groups of 10 . Group I was treated with daily mud packs, group II with daily hot sulphur baths, group III with a combination of mud packs and hot sulphur baths, and group IV served as a control group. The patients were assessed by a rheumatologist who was blinded to the treatment modalities. Statistically significant improvement for a period of up to three months was observed in the three treatment groups in most of the clinical indices. Improvement in the control group was minor in comparison and not statistically significant. No significant improvement was observed in any of the laboratory variables measured. Except for three mild cases of thermal reaction there were no side effects.
\end{abstract}

The role of balneotherapy in rheumatology is a subject of much debate. Although it has been a major therapeutic approach in Europe for many years, it is not popular and its value is often questioned in other countries, including the United States. The efficacy of sulphur baths and mud pack treatment in rheumatoid arthritis is still debatable. According to Cosh patients with active and widespread disease are best treated in hospitals and only when remission is achieved should spa treatment be considered. ${ }^{1}$

In Israel the main health resort area is located along the western shore of the Dead Sea at the southern end of the Jordan river. This area is renowned for its many hot thermomineral springs, rich in sulphur and other minerals. It especially suited for therapeutic purposes.

The aim of this study was to evaluate the effectiveness of mud packs and sulphur baths in patients with severe, active rheumatoid arthritis.

Soroka Medical Center and the Faculty of Health

Sciences, Ben-Gurion

University of the Negev, Beer-Sheva, Israel

L Neumann

Toor Institute of Clinical Biochemistry, Soroka Medical Center and the Faculty of Health Sciences, Ben-Gurion University of the Negev, Beer-Sheva, Israel

$S$ Zimlichman

Correspondence to: Dr $S$ Sukenik, Soroka Medica Center, PO Box 15 Beer-Sheva, Israel.

Accepted for publication 15 May 1989

\section{Materials and methods}

Forty patients (32 women, eight men) with definite or classical rheumatoid arthritis as defined by American Rheumatism Association criteria $^{2}$ were treated for a period of two weeks at the Moriah Spa Hotel. Patients suffering from diseases such as active ischaemic heart disease, uncontrolled diabetes mellitus, severe hypertension, peripheral vascular disease, or central nervous system diseases, such as epilepsy, were excluded from the study. The patients were randomly allocated into four has a large natural concentration of mud

groups of 10 patients each. Group I was treated with daily mud packs heated to $42^{\circ} \mathrm{C}$ and applied over the four extremities, neck, and back for 20 minutes each day. Group II was treated with daily sulphur baths heated at $37^{\circ} \mathrm{C}$ for 20 minutes each day. Group III was treated with a combination of daily mud packs (as in group I) and daily sulphur baths (as in group II). Group IV served as a control group, receiving neither mud packs nor sulphur baths. Controls were aware of the other three groups and of the treatment they were receiving. Apart from the treatment itself patients in the control group had the same degree of activity and rest as those in the other groups.

Table 1 summarises the demographic and clinical characteristics of the patients. Most of the patients were in functional class II and anatomical (progression of rheumatoid arthritis) stage III. ${ }^{3}$ Table 2 summarises the drugs taken throughout the study period. Most of the patients took disease remitting drugs, such as oral or intramuscular gold preparations, penicillamine, methotrexate, or azathioprine. A few patients in each group also took systemic steroids in low doses. All patients in all groups continued to receive their regular treatment, including non-steroidal anti-inflammatory drugs, disease remitting drugs, and systemic steroids without any change in type or dose. All patients receiving disease remitting drugs had

Table 1: Demographic and clinical characteristics of the patients by treatment group

\begin{tabular}{|c|c|c|c|c|}
\hline & $\begin{array}{l}\text { Mud } \\
\text { packs }\end{array}$ & $\begin{array}{l}\text { Sulphur } \\
\text { baths }\end{array}$ & $\begin{array}{l}\text { Mud packs and } \\
\text { sulphur baths }\end{array}$ & Control \\
\hline Male/female ratio & $3: 7$ & $1: 9$ & $1: 9$ & $3: 7$ \\
\hline $\begin{array}{l}\text { (years) } \\
\text { Disease duration }\end{array}$ & $49 \cdot 0$ & $56 \cdot 8$ & $52 \cdot 3$ & $52 \cdot 4$ \\
\hline & 6.4 & $10 \cdot 3$ & $8 \cdot 2$ & 8.5 \\
\hline II & $\begin{array}{l}7 \\
3\end{array}$ & $\begin{array}{l}9 \\
1\end{array}$ & $\begin{array}{l}9 \\
1\end{array}$ & $\begin{array}{l}8 \\
2\end{array}$ \\
\hline $\begin{array}{l}\text { Anatomical stage } \\
\text { II } \\
\text { III }\end{array}$ & $\begin{array}{r}0 \\
10\end{array}$ & $\begin{array}{l}1 \\
9\end{array}$ & $\begin{array}{l}1 \\
9\end{array}$ & $\begin{array}{l}1 \\
9\end{array}$ \\
\hline
\end{tabular}

Table 2: Drugs in use by the patients by treatment group

\begin{tabular}{|c|c|c|c|c|}
\hline & $\begin{array}{l}\text { Mud } \\
\text { packs }\end{array}$ & $\begin{array}{l}\text { Sulphur } \\
\text { baths }\end{array}$ & $\begin{array}{l}\text { Mud packs and } \\
\text { sulphur baths }\end{array}$ & Control \\
\hline $\begin{array}{l}\text { NSAIDs* } \\
\text { Remitting drugs } \\
\text { Steroids }\end{array}$ & $\begin{array}{r}10 \\
8\end{array}$ & $\begin{array}{l}10 \\
10\end{array}$ & $\begin{array}{l}9 \\
9\end{array}$ & $\begin{array}{r}10 \\
7\end{array}$ \\
\hline $\begin{array}{l}\text { (prednisone) } \\
\text { Mean dose } \\
\text { (mg) }\end{array}$ & $\begin{array}{c}4 \\
10 \cdot 0\end{array}$ & $12 \cdot 0$ & $7 \cdot 5$ & $9 \cdot 2$ \\
\hline
\end{tabular}

*NSAIDs=non-steroidal anti-inflammatory drugs.

fOral and intramuscular gold, penicillamine, azathioprine, methotrexate. 
started this treatment at least six months before the start of the study.

All patients were assessed by one rheumatologist who was blinded to the mode of treatment. He first examined the patients at the outpatient clinic of the Soroka Medical Center two to three days before arrival at the spa hotel (phase 0), then at the Moriah Spa Hotel clinic one week after start of treatment and at the end of treatment, and, finally, one month and three months after completion of treatment, at the outpatient clinic of the Soroka Medical Center.

The clinical indices assessed at each examination were $(a)$ duration of morning stiffness (in minutes); (b) 15 metre walk time (in seconds); (c) right and left hand grip strength using a standard recorder (in $\mathrm{mmHg}$ ); (d) circumferences of the proximal interphalangeal joints of the four fingers of each hand (in $\mathrm{mm}$ ). This was measured by using rings of varying diameters and determining the smallest ring that would pass over each joint. The sum of the circumferences of the joints measured in both hands was divided by the number of joints thus yielding an average circumference of proximal interphalangeal joints for both hands; $(e)$ activities of daily living on a scale of $1-6$, in which $1=$ very poor, $2=$ poor, $3=$ fair, $4=$ good, $5=$ very good, and $\mathbf{6}=$ excellent; $(f)$ patient assessment of disease severity on a scale of $0-10$, in which $0=$ the most severe situation and 10 the ideal situation according to the patient's individual perception; $(g)$ number of active joints. A joint was defined as active when at least one of the following findings was present: soft tissue swelling; intraarticular effusion; tenderness over the joint line; and stress pain; $(h)$ the Ritchie index. ${ }^{4}$

The laboratory variables assessed were complete blood count, Westergren erythrocyte sedimentation rate, rheumatoid factor titres measured by Beckman immunochemistry systems rate nephelometry (normal values $<60$ $\mathrm{IU} / \mathrm{ml}$ ), and serum amyloid A protein measured by radioimmunoassay using purified amyloid $\mathrm{A}$ protein from human amyloidogenic spleen of a patient with familial Mediterranean fever and rabbit antibody against human amyloid A (normal serum concentration $<2 \mathrm{pg} / \mathrm{ml}$ ). ${ }^{5}$

Wilcoxon's non-parametric test was used to compare clinical and laboratory indices obtained at each assessment interval with those of phase 0 .

\section{Results \\ CLINICAL ASSESSMENT \\ Morning stiffness}

Significant reductions in duration of morning stiffness were achieved in each treatment modality compared with the control group (table 3). Maximal improvement was observed at the end of the treatment and lasted for about one month.

\section{Fifteen metre walk time}

Group III (combination treatment) showed the best results for the $15 \mathrm{~m}$ walk time. The effect lasted no more than one month after completion of treatment (table 4).

\section{Hand grip}

Significant improvement in hand grip was seen in all the treated groups and less in the control group (table 5).

Circumference of proximal interphalangeal joints Swelling of the proximal interphalangeal joints

Table 3: Duration of morning stiffness by treatment group (mean values in minutes)

\begin{tabular}{llllll}
\hline & Phase 0 & 1 Week & 2 Weeks & 1 Month & 3 Months \\
\hline Mud packs & 80 & $63^{*}$ & $51^{* *}$ & 71 & 93 \\
Sulphur baths & 95 & $67^{*}$ & $52^{* *}$ & $39^{* *}$ & $41^{* *}$ \\
Mud packs and sulphur baths & 69 & $51^{*}$ & $29^{* *}$ & $36^{*}$ & 70 \\
Control & 86 & 77 & 72 & 76 & $65^{*}$
\end{tabular}

${ }^{*} \mathrm{p}<0.05$ compared with phase 0 .

${ }^{* *} \mathrm{p}<0.01$ compared with phase 0 .

Table 4: Fifteen metre walk time by treatment group (mean values in seconds)

\begin{tabular}{llllll}
\hline & Phase 0 & 1 Week & 2 Weeks & 1 Month & 3 Months \\
\hline Mud packs & $16 \cdot 0$ & $14 \cdot 1^{* *}$ & $12 \cdot 9^{* * *}$ & $13 \cdot 1^{*}$ & 15 \\
Sulphur baths & $14 \cdot 7$ & $13 \cdot 3^{*}$ & $15^{*}$ & $12 \cdot 9^{*}$ & $13 \cdot 2$ \\
Mud packs and sulphur baths & $15 \cdot 5$ & $13 \cdot 2^{* *}$ & $12 \cdot 6^{* *}$ & $12 \cdot 9^{* * *}$ & $14 \cdot 3$ \\
Control & $13 \cdot 7$ & $13 \cdot 7$ & $13 \cdot 3$ & $12 \cdot 7^{*}$ & $12 \cdot 9$ \\
\hline
\end{tabular}

${ }^{*} \mathrm{p}<0.05$ compared with phase 0 .

${ }^{* *} \mathrm{p}<0.01$ compared with phase 0 .

Table 5: Hand grip (right and left) by treatment group (mean values in $\mathrm{mmHg}$ )

\begin{tabular}{llllll}
\hline & Phase 0 & 1 Week & 2 Weeks & 1 Month & 3 Months \\
\hline Mud packs & 123 & $147^{* *}$ & $163^{* *}$ & $156^{*}$ & 139 \\
Sulphur baths & 118 & $136^{* *}$ & $137^{* *}$ & $133^{*}$ & 129 \\
Mud packs and sulphur baths & 113 & $141^{* *}$ & $156^{* *}$ & $156^{* *}$ & 127 \\
Control & 124 & $137^{*}$ & $140^{* *}$ & 135 & 128 \\
\hline${ }^{*} \mathrm{p}<0.05$ compared with phase 0. & & & & \\
${ }^{* *} \mathrm{p}<0.01$ compared with phase 0. & & & &
\end{tabular}


was reduced significantly in groups I and III. Sulphur baths alone were not effective and the significant reduction observed in this group and in the control group at the last assessment is probably coincidental or an error of measurement (table 6).

\section{Activities of daily living}

Significant improvement in the activities of daily living was observed in all four groups. After three months only the control group and group I continued to show significant improvement (table 7).

\section{Patient assessment of disease severity}

Significant and lasting improvement of disease severity based on patient self assessment was found in the three treatment groups (table 8).

Number of active joints and Ritchie index

An impressive reduction in the number of active joints and improvement in the Ritchie index was observed in the treatment groups. This improvement reached its maximal effect at the end of two weeks and continued to be significant three months after completion of treatment (figs 1 and 2).

Table 6: Proximal interphalangeal circumference measured in four fingers of each hand by treatment group (mean values of the sum in millimetres)

\begin{tabular}{|c|c|c|c|c|c|}
\hline & Phase 0 & l Week & 2 Weeks & 1 Month & 3 Months \\
\hline \multirow{2}{*}{$\begin{array}{l}\text { Mud packs } \\
\text { Sulphur baths } \\
\text { Mud packs and } \\
\text { sulphur baths } \\
\text { Control }\end{array}$} & $\begin{array}{l}63.4 \\
58.9\end{array}$ & $\begin{array}{l}62 \cdot 1^{*} \\
57 \cdot 8\end{array}$ & $\begin{array}{l}62 \cdot 1^{* *} \\
57 \cdot 4\end{array}$ & $\begin{array}{l}62^{* * *} \\
57 \cdot 2\end{array}$ & $\begin{array}{l}61 \cdot 6^{* *} \\
57 \cdot 0^{*}\end{array}$ \\
\hline & $\begin{array}{l}58.8 \\
61 \cdot 6\end{array}$ & $\begin{array}{l}57 \cdot 8^{*} \\
61 \cdot 1\end{array}$ & $\begin{array}{l}57 \cdot 7^{* *} \\
61 \cdot 4\end{array}$ & $\begin{array}{l}58.9^{*} \\
61 \cdot 0\end{array}$ & $\begin{array}{l}58 \cdot 5 \\
60 \cdot 6^{*}\end{array}$ \\
\hline
\end{tabular}

${ }^{*} p<0.05$ compared with phase 0

${ }^{* *} \mathrm{p}<0.01$ compared with phase 0 .

Table 7: Activities of daily living by treatment group (scale of 1-6) $t$

\begin{tabular}{llllll}
\hline & Phase 0 & 1 Week & 2 Weeks & 1 Month & 3 Months \\
\hline Mud packs & $2 \cdot 5$ & $3 \cdot 1^{*}$ & $4 \cdot 0^{* *}$ & $3 \cdot 4^{*}$ & $3 \cdot 1^{*}$ \\
$\begin{array}{l}\text { Sulphur baths } \\
\text { Mud packs and }\end{array}$ & $2 \cdot 8$ & $3 \cdot 2$ & $3 \cdot 2$ & $3 \cdot 3$ & $3 \cdot 2$ \\
$\begin{array}{l}\text { sulphur baths } \\
\text { Control }\end{array}$ & $2 \cdot 8$ & $3 \cdot 4^{*}$ & $3 \cdot 9^{* *}$ & $3 \cdot 3$ & $2 \cdot 6$ \\
& $2 \cdot 6$ & $3 \cdot 0$ & $3 \cdot 1^{*}$ & $3 \cdot 2^{*}$ & $3 \cdot 2^{*}$
\end{tabular}

${ }^{*} \mathrm{p}<0.05$ compared with phase 0 .

†Scale: $1=$ very poor; $2=$ poor; $3=$ fair; $4=$ good; $5=$ very good; $6=$ excellent.

Table 8: Patient assessment of disease severity by treatment group (scale of 0-10)t

\begin{tabular}{|c|c|c|c|c|c|}
\hline & Phase 0 & l Week & 2 Weeks & 1 Month & 3 Months \\
\hline $\begin{array}{l}\text { Mud packs } \\
\text { Sulphur baths } \\
\text { Mud packs and }\end{array}$ & $\begin{array}{l}4 \cdot 1 \\
5 \cdot 0\end{array}$ & $\begin{array}{l}5 \cdot 1^{* *} \\
6 \cdot 1^{* *}\end{array}$ & $\begin{array}{l}6 \cdot 5^{* *} \\
6 \cdot 4^{* *}\end{array}$ & $\begin{array}{l}6 \cdot 1^{* *} \\
6 \cdot 4^{*}\end{array}$ & $\begin{array}{l}5 \cdot 7^{* *} \\
6 \cdot 3^{*}\end{array}$ \\
\hline $\begin{array}{l}\text { sulphur baths } \\
\text { Control }\end{array}$ & $\begin{array}{l}4 \cdot 8 \\
5 \cdot 5\end{array}$ & $\begin{array}{l}6 \cdot 3^{* * *} \\
6 \cdot 0\end{array}$ & $\begin{array}{l}7 \cdot 0^{* *} \\
6 \cdot 1\end{array}$ & $\begin{array}{l}7 \cdot 0^{*} \\
5 \cdot 9\end{array}$ & $\begin{array}{l}5 \cdot 7^{*} \\
5 \cdot 7\end{array}$ \\
\hline
\end{tabular}

${ }_{*}^{*} \mathrm{p}<0.05$ compared with phase 0

${ }^{* *} \mathrm{p}<0.01$ compared with phase 0 .

tScale: $0=$ the most severe situation; $10=$ the ideal situation.

Table 9: Erythrocyte sedimentation rate by treatment group (mean value in $\mathrm{mm} / \mathrm{h}$ )

\begin{tabular}{|c|c|c|c|c|c|}
\hline & Phase 0 & $l$ Week & 2 Weeks & 1 Month & 3 Months \\
\hline $\begin{array}{l}\text { Mud packs } \\
\text { Sulphur baths } \\
\text { Mud packs and }\end{array}$ & $\begin{array}{l}38 \cdot 7 \\
32 \cdot 0\end{array}$ & $\begin{array}{l}39 \cdot 0 \\
34 \cdot 3\end{array}$ & $\begin{array}{l}33 \cdot 2 \\
30 \cdot 7\end{array}$ & $\begin{array}{l}34 \cdot 3 \\
34 \cdot 3\end{array}$ & $\begin{array}{l}30 \cdot 8 \\
25 \cdot 5\end{array}$ \\
\hline $\begin{array}{l}\text { sulphur baths } \\
\text { Control }\end{array}$ & $\begin{array}{l}31 \cdot 0 \\
39 \cdot 3\end{array}$ & $\begin{array}{l}32 \cdot 0 \\
45 \cdot 3\end{array}$ & $\begin{array}{l}28 \cdot 1 \\
43 \cdot 8\end{array}$ & $\begin{array}{l}26 \cdot 1 \\
43 \cdot 7\end{array}$ & $\begin{array}{l}28 \cdot 2 \\
38 \cdot 2\end{array}$ \\
\hline
\end{tabular}

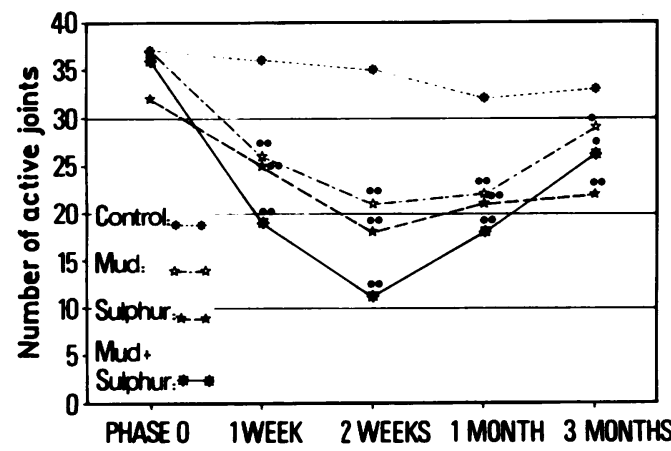

Figure 1: Number of active joints.

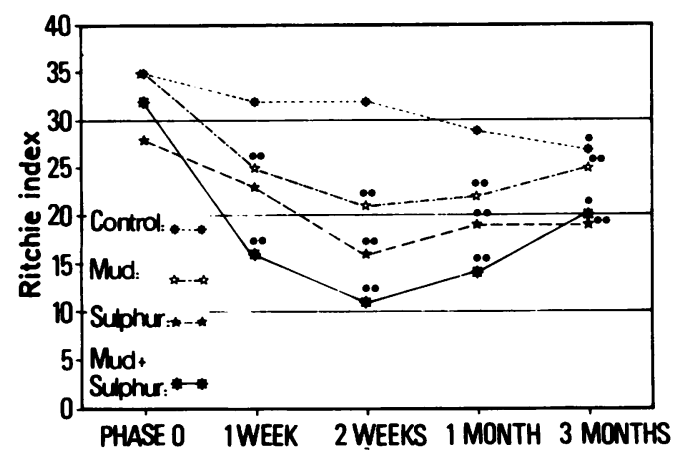

Figure 2: Ritchie index.

LABORATORY ASSESSMENT

No significant differences were observed among the four groups in the erythrocyte sedimentation rates (table 9) or levels of rheumatoid factor and serum amyloid $\mathrm{A}$.

SIDE EFFECTS

There were three mild cases of thermal reaction, which resolved spontaneously after a few days and did not require treatment to be stopped. No other side effects were observed.

\section{Discussion}

Although balneotherapy as a special form of physiotherapy is often recommended in mild cases of rheumatoid arthritis, there are still doubts about its efficacy and safety in patients with actively inflamed joints. This unique and prospective study was designed to evaluate the safety and efficacy of mud packs and sulphur baths alone or in combination in patients suffering from active and severe rheumatoid arthritis. One of the advantages of this study was the continuing close follow up provided for all patients after completion of the treatment period at the spa hotel.

The results of this study show that the three modalities of treatment-mud packs alone, sulphur bath alone, or the combination of both-are effective and safe in cases of active disease. Generally, somewhat better results were obtained in group III patients, who were treated by a combination of mud pack and sulphur baths, but for some clinical indices better results were seen in groups I or II. The maximal therapeutic effect was usually observed at the end of the treatment and lasted for between one and three months. Significant 
improvement of a few variables was found in the control group. Nevertheless, this improvement was always less impressive than that seen in the treatment groups. This was not totally unexpected as we know that even the temporary change in lifestyle occasioned by admission to hospital may lead to clinical improvement. ${ }^{6}$

The mechanism by which spa treatment works is not fully understood. Immersion in spa water causes many physiological changes, such as significant diuresis and natriuresis, ${ }^{7}$ haemodilatation, ${ }^{8}$ and an increase in cardiac output without a significant change in blood pressure. $^{9-11}$ It is not clear whether these physiological changes have any influence on the disease process, but it is clear that muscle tone, joint mobility, and pain intensity are influenced by these hydromechanical and thermal stimuli. Grahame et al showed that immersion in a hydrotherapy pool for one hour provoked a significant diuresis, natriuresis, and kaliuresis associated with significant reduction of the circumference of the proximal interphalangeal joints of patients suffering from rheumatoid arthritis. ${ }^{12}$

Although trace elements such as zinc and copper may be important in the pathogenesis of rheumatoid arthritis, it is not clear if these and other trace elements can be absorbed through the skin. O'Hare et al found no evidence for absorption of calcium, magnesium, or sodium. ${ }^{7}$ Shani et al, on the other hand, showed significant increases in the concentration of $\mathrm{Br}, \mathrm{Rb}$, $\mathrm{Ca}$, and $\mathrm{Zn}$ in patients suffering from psoriasis after bathing in the Dead Sea. ${ }^{13}$ Lately it has been shown that low serum zinc and increased serum copper are common in rheumatoid arthritis and that the extent and severity of the immune inflammatory rheumatoid process is associated with low serum zinc concentration. ${ }^{14}$ Zinc and copper are present in very small quantities in both our mud packs and sulphur baths. We plan future studies to clarify the question of possible percutaneous absorption of these trace elements.

The clinical improvement found with all three treatment modalities was not associated with any improvement in laboratory variables. Erythrocyte sedimentation rate and serum amyloid A concentration did not fall. Baseline values for erythrocyte sedimentation rates were relatively low in all four groups (table 9), which may explain the fact that no significant decrease was found in this variable. Serum amyloid A is an acute phase protein synthesised mostly in the liver under the influence of interleukin 1 . Serum concentrations of amyloid A have been shown to correlate with disease activity in cases of rheumatoid activity. ${ }^{15}$ Although the initial concentrations of serum amyloid A were well above normal in all four groups of patients, no significant fall was observed during clinical improvement. We have no explanation for this 'clinical-laboratory dissociation', but it has been described in other studies also. ${ }^{16} 17$

Balneotherapy is considered to be contraindicated in patients with acute attacks of rheumatoid arthritis or active disease. ${ }^{18}$ Despite the fact that most of our patients fell into these categories there were only three cases of mild thermal reaction, which did not require treatment to be stopped. No clinical aggravation, even temporary in nature, due to spa treatment was found.

We conclude that mud packs and sulphur baths alone or in combintion are safe and effective in reducing objective and subjective indices of rheumatoid arthritis activity for a period of up to three months. We realise that further studies based on larger patient populations are needed to confirm our findings about the safety and efficacy of these modes of treatment.

We thank Professor J Bearman for help in designing this study, and the nurses B Loebel and R Bar for their help in carrying it out. Supported in part by a grant from Mifal Hapayis foundation in memory of Pinchas Sapir.

1 Cosh J A. The rheumatologist and the spa, a personal view. Royal Society of Health Fournal 1982; 102: 189-92.

2 Ropes M W, Bennett G A, Cobb S, Jacox R, Jessar R A

Revision of diagnostic criteria for rheumatoid arthritis. Bul Rheum Dis 1958; 9: 175-6.

3 Steinbrocker O, Traeger C H, Batterman R C. Therapeutic Steinbrocker $\mathrm{O}$, Traeger $\mathrm{C} \mathrm{H}$, Batterman $\mathrm{R} C$. Therapeutic
criteria in rheumatoid arthritis. $\mathcal{F A M A} 1949 ; 140: 659-62$.

4 Ritchie D M, Boyle J A, McInnes J M. Clinical studies with an articular index for the assessment of joint tenderness in patients with rheumatoid arthritis. $Q \mathcal{F}$ Med 1968; 37: 393-6.

5 Shainkin-Kestenbaum R, Zimlichman S, Winikoff Y. Serum amyloid A in viral infection. Clin Exp Immunol 1982; 50 503-6.

6 Lee P, Kennedy A C, Anderson J, Buchmann W. Benefits of hospitalization in rheumatoid arthritis. $Q \mathcal{F}$ Med 1974; 43: 205-14.

7 O'Hare J P, Heywood A, Summerhayes C, et al. Observations on the effects of immersion in Bath spa water. Br Med $\mathcal{F}$ 1985 291: 1747-51.

8 O'Hare J P, Heywood A, Dodds P, Corrall R J M, Dieppe P. Water immersion in rheumatoid arthritis [Abstract]. $B r \dot{f}$ Rheumatol 1984; 23: 117.

9 Arborelius M, Ballidim U, Lilja B, Lungren C. Hemoglobin changes in man during immersion head above water. Aerospace Medicine 1972; 43: 592-8.

10 Rennie D, Diprampero P, Carretelli P. Effects of water immersion on cardiac output, heart rate and stroke volume of man at rest and during exercise. Medicina dello Sport 1971; 24: 223-8.

11 Bennet E D, Barclay S, Mannering D, Mehta N. The noninvasive assessment of left ventricular performance using Doppler ultrasound. Clin Sci 1984; 66: 80.

12 Grahame R, Hunt J, Kitchen S. The diuretic and natriuretic effect of water immersion-possible rationale for balneotherapy [Abstract]. Ann Rheum Dis 1978; 37: 567.

13 Shani J, Barak S, Levi D, et al. Skin penetration of minerals in psoriatics and guinea-pigs bathing in hypertonic salt solution. Pharmacol Res Commun 1985; 17: 501-23.

14 Mussalo-Rauhamaa H, Konttinen Y T, Lehto J, Honkanen $V$. Predictive clinical and laboratory parameters for serum zinc and copper in rheumatoid arthritis. Ann Rheum $D i$ 1988; 47: 816-9.

15 Chambers R E, Macfarlane D G, Whicher J T. Serum amyloid A protein concentration in rheumatoid arthritis and its role in monitoring disease activity. Ann Rheum Dis its role in monit

16 Jordan H. Dynamics of the clinical and paraclinical criteria of the activity of rheumatoid arthritis and their use in assessing the therapeutic effects of mud treatment (peat and silk muds). Vopr Kurortol Fizioter Lech Fiz Kult 1986; 4: 27-31.

17 Trink R F. Quantitative evaluation of the effectiveness of health resort therapy in rheumatoid arthritis. Reumatologiia (Moskva) 1983; 3: 44-6.

18 Behrend T. The balneotherapy of rheumatoid arthritis. Rheumology and Rehabilitation 1977; suppl: 86-7. 